University of Nebraska - Lincoln

DigitalCommons@University of Nebraska - Lincoln

1994

\title{
A Metapopulation Approach to Pitcher's Thistle (Cirsium pitcheri) Recovery in Southern Lake Michigan Dunes
}

A. Kathryn McEachern

USGS Channel Islands Field Station

Marlin L. Bowles

Morton Arboretum, Lisle, IL

Noel B. Pavlovic

Univ. of Illinois-Chicago

Follow this and additional works at: https://digitalcommons.unl.edu/usgsstaffpub

Part of the Earth Sciences Commons

McEachern, A. Kathryn; Bowles, Marlin L.; and Pavlovic, Noel B., "A Metapopulation Approach to Pitcher's Thistle (Cirsium pitcheri) Recovery in Southern Lake Michigan Dunes" (1994). USGS Staff -- Published Research. 239.

https://digitalcommons.unl.edu/usgsstaffpub/239

This Article is brought to you for free and open access by the US Geological Survey at DigitalCommons@University of Nebraska - Lincoln. It has been accepted for inclusion in USGS Staff -- Published Research by an authorized administrator of DigitalCommons@University of Nebraska - Lincoln. 


\title{
8
}

\section{A metapopulation approach to Pitcher's thistle (Cirsium pitcheri) recovery in southern Lake Michigan dunes}

\author{
A. KATHRYN MCEACHERN, MARLIN L. BOWLES \\ AND NOEL B. PAVLOVIC
}

\section{Introduction}

Successful recovery planning for a rare species relies upon knowledge of its life history and ecology, as well as an understanding of its habitat requirements and disturbance regime (Gilpin \& Soulé 1986, Lande 1988a). Species that depend upon early-successional or transient habitats in landscape mosaics present unique recovery challenges (Menges 1990). They require perpetuation of multiple populations within a shifting mosaic of local habitats. Recovery plans for these species must be formulated from an understanding of population demography within the context of community and landscape dynamics. Processes that maintain landscape mosaics must be given long-term protection if recovery is to succeed.

Pitcher's thistle, Cirsium pitcheri (Torr.) T. and G., is listed as threatened in the United States and Canada (Harrison 1988). This monocarpic plant is endemic to the western Great Lakes sand dunes. It is an early-successional species that colonizes open patches in dynamic dune landscapes (Pavlovic et al. 1993). Its recovery depends upon the perpetuation of interacting mosaics of populations, or metapopulations, in Great Lakes dune systems. The concept of metapopulation dynamics (Levins 1970, den Boer 1981, Gilpin 1987, Goodman 1987a, Gilpin \& Hanski 1991) is useful for understanding Cirsium pitcheri ecology and management options. It describes species persistence in environments where the probability of local extinction is high, and has applications to species recovery and reserve design (e.g., Shaffer 1981, Gilpin \& Soulé 1986, Goodman 1987b, Lande 1988b, Menges 1990, Murphy, Freas \& Weiss 1990). In this chapter, we present a recovery model for Pitcher's thistle based upon metapopulation theory and apply it to recovery sites in Illinois and Indiana. 


\section{Metapopulation theory and recovery of rare plants}

Metapopulation theory provides a framework linking landscape processes with population dynamics, which is essential to understanding mechanisms of species persistence in fluctuating environments. A metapopulation is a collection of interacting populations dispersed through a spatially and temporally variable landscape. The fate of each population is influenced by its genetic, demographic, and environmental history. Variability among populations contributes to metapopulation characteristics, which develop within the physical and biological constraints of the landscape. Landscape processes can influence metapopulation dynamics on at least two levels. At a coarse scale, landscape habitat dispersion and dynamics affect metapopulation patterning in space and time. At a fine scale, fates of individuals are influenced by their interactions with local biotic and abiotic factors, affecting extinction probabilities of locally distributed populations.

Shaffer (1981) identified four causes of population extinction, which can be applied to the components of a metapopulation. Two, widespread catastrophes and local environmental stochasticity, can affect all members of a population simultaneously and can drive both small and large populations to extinction. The other two, demographic and genetic stochasticity, produce variation in survival of individuals. They can drive very small populations to extinction, whereas the extinction probabilities of larger populations are determined to a greater extent by environmental events. Thus, these causes drive population dynamics differently because of the ways they affect overall variance in population growth rates over different population sizes (Goodman 1987a).

Metapopulations can persist even when the rate of component population extinction is high (Menges 1990, Murphy et al. 1990). Metapopulation persistence depends upon the balance between landscape and population dynamics (Goodman 1987b). First, population establishment rates must equal or exceed population extinction rates. Second, local environmental events causing population decline must act on populations independently. Third, spatial variation in demographic processes must occur, ensuring that not all populations will decline or be extirpated at the same time.

A metapopulation framework allows examination of species persistence with explicit reference to mechanisms interacting at different scales (Fig. 8.1). At a fine scale, variation in individual population demographic structure and dynamics can be correlated with local environmental processes. At a coarse scale, metapopulation structure can be correlated with demographic variation among populations, landscape patch dynamics and population dispersion, and 


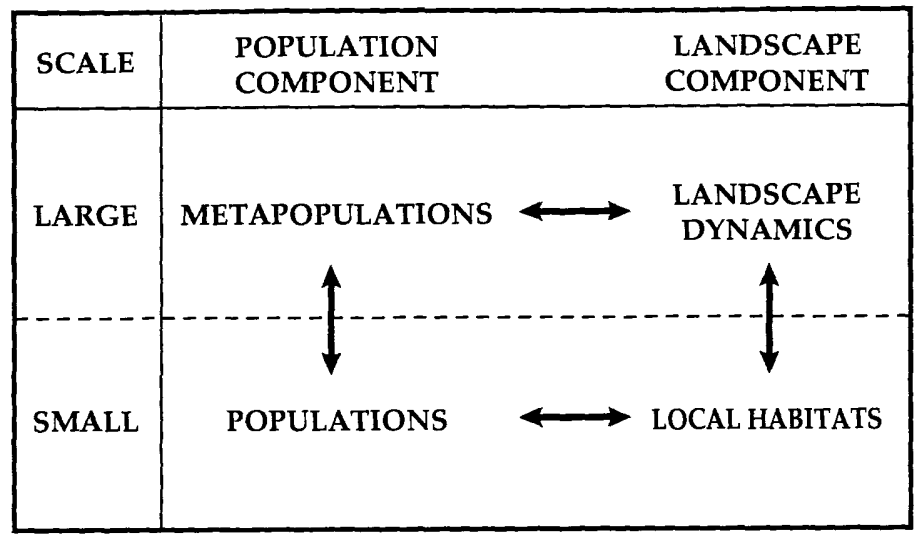

Fig. 8.1. Scalar considerations in applying metapopulation dynamics to species management.

fluctuations in the magnitudes and frequencies of landscape-scale environmental processes. Management or recovery prescriptions can then be focused at the appropriate population or habitat level.

\section{Great Lakes dune environments and Pitcher's thistle}

\section{Landscape dynamics}

The Great Lakes dunes are structurally variable, dynamic systems, ranging from linear beaches and foredunes to extensive dune complexes. Their vegetation is a series of early- to late-successional community stages (Cowles 1899) across beach, foredune, dune trough and secondary dune zones (Fig. 8.2) in response to gradients of increasing dune age and decreasing wind and wave disturbance (Olson 1958a). Early-successional vegetation can also be maintained on windward faces of secondary dunes, or it can be established in blowouts created by storms or human impacts. Blowouts undergo rapid succession if disturbance is not sustained, losing their colonizing species over several decades (Olson 1958b). Similar succession can occur on dunes that become sheltered or experience decreased winds due to climate fluctuation.

Great Lakes dune systems are built from sand supplied by longshore currents. They are shaped in response to prevailing wind direction and velocity, and in response to coastline configuration relative to storm tracks (Fig. 8.3) (Larsen 1985, Thompson 1989). There are at least two disturbance regimes that affect the availability of open habitats that can be colonized by $C$. pitcheri (Fig. 8.2). One is the stochastic occurrence of severe storms that erode beaches 

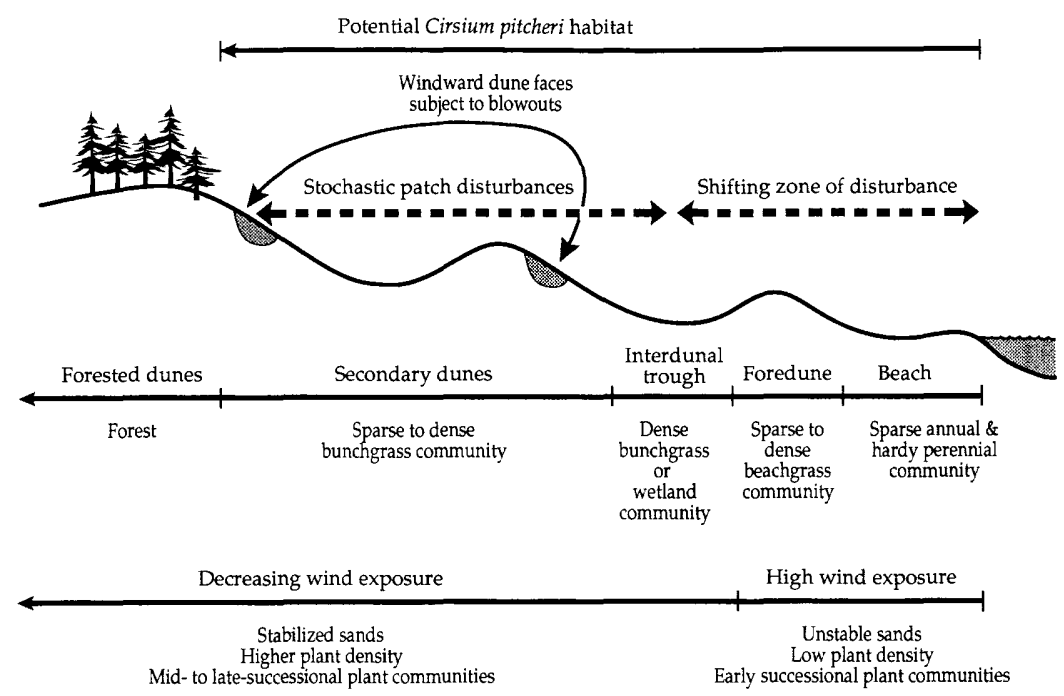

Fig. 8.2. Disturbance, successional gradients, and Cirsium pitcheri habitat distribution across Great Lakes dune systems (redrawn from Pavlovic et al. 1993).

and open inland blowouts. The other is a nested cycle of dune system responses to annual and longer-term climate change. Shorelines characteristically recede during fall and early winter periods of storm erosion and rebuild during spring and summer. They also undergo more severe erosion and accretion cycles as lake levels fluctuate in response to climate shifts. Lake Michigan levels fluctuate on approximately 30-year cycles nested within 100-year and 300-year cycles (Olson 1958b, Larsen 1985, Thompson 1987). Lakes Superior and Huron undergo similar fluctuations, but have slightly different cycle periods and magnitudes of change (Farrand \& Drexler 1985).

Lake level fluctuations cause dune habitats to shift differently in space over time, depending upon their locations. For example, during high lake levels, beaches and foredunes erode and shift inland, while more inland dunes may remain stable or lose sand on their windward faces. During low lake levels, new lakeward dunes are built and these further shelter the inland dunes. In contrast, dunes perched upon bluffs receive sand nourishment when high lake levels undercut and destabilize bluff faces (Marsh \& Marsh 1987), but stabilize during low lake levels when bluff faces are stable. Therefore, dune system responses to climate change occur differently in different parts of dune fields and lake basins. Such cyclic and stochastic processes of dune building and erosion have been operating in the Great Lakes at least since the late Holocene (Farrand \& Drexler 1985, Larsen 1985, Hansel \& Mickelson 1988, Thompson 1989). 


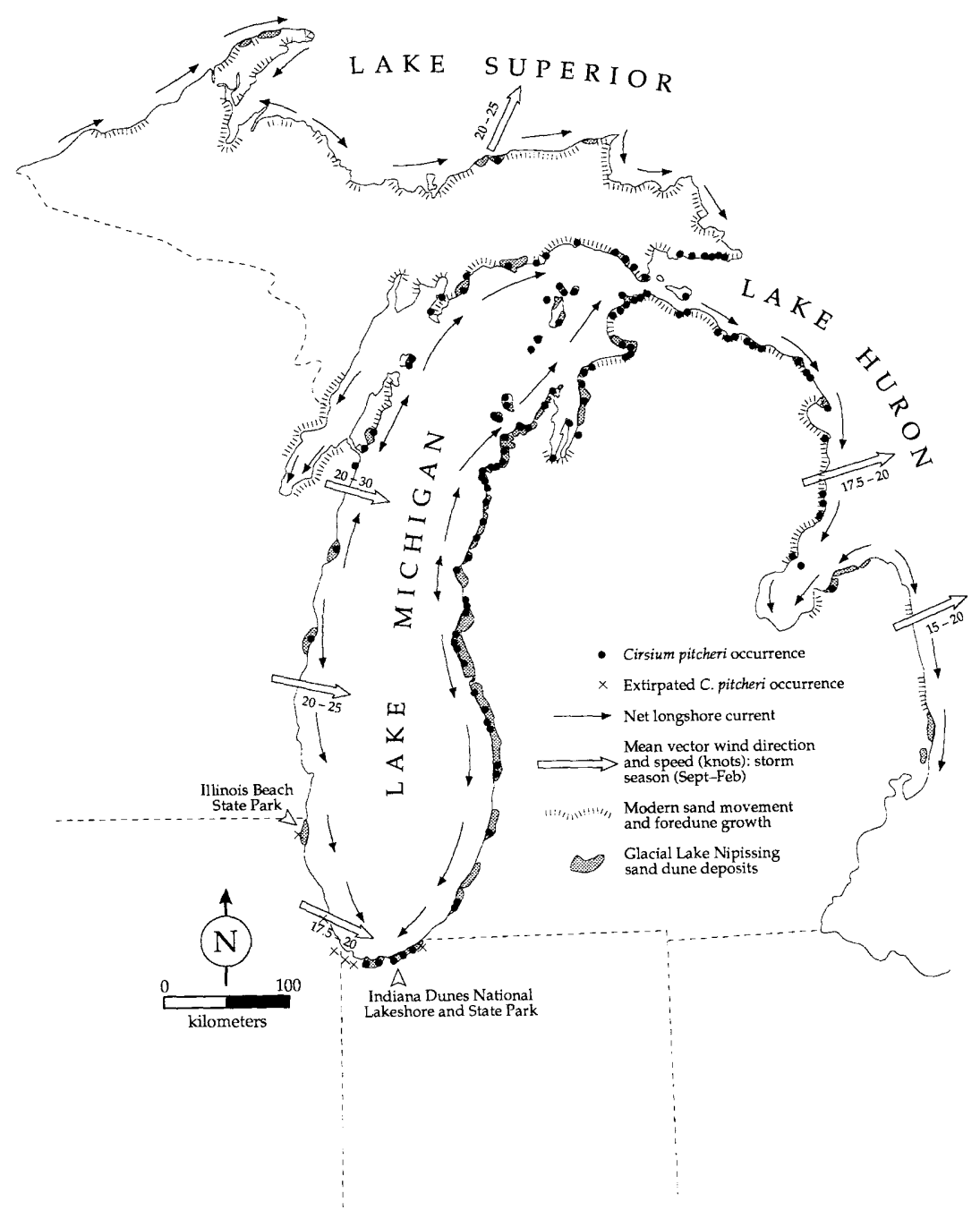

Fig. 8.3. Cirsium pitcheri species and habitat distribution and shoreline dynamics of western Great Lakes dune systems (redrawn from: Bird \& Schwartz 1985, Dorr \& Eschman 1971, Hands 1970, Saulesleja 1986, Pavlovic et al. 1993).

\section{Metapopulation adaptations}

Because individual populations may have high extinction probabilities, Cirsium pitcheri population dynamics must be considered at both the landscape (metapopulation) and local habitat (population) levels. Seed dispersal from existing populations allows thistles to become established in open habitat throughout the beach and grassland portion of the dune landscape (Pavlovic et 
Table 8.1. Characteristics of habitat patches inhabited by Cirsium pitcheri in Great Lakes dunes (modified from McEachern 1992).

Data collected from northern Indiana and northeastern lower Michigan on Lake Michigan, and upper peninsula Michigan on Lake Superior; groups were identified by Ward's cluster analysis of plant communities.

\begin{tabular}{|c|c|c|c|}
\hline Characteristic & Group 1 & Group 2 & Group 3 \\
\hline Successional rank & Early & Mid & Late \\
\hline Topographic position & $\begin{array}{l}\text { Foredunes and } \\
\text { blowouts }\end{array}$ & Blowouts & Secondary dunes \\
\hline Disturbance regime & $\begin{array}{l}\text { Cyclically shifting } \\
\text { nearshore zone } \\
\text { and stochastically } \\
\text { created inland } \\
\text { patches }\end{array}$ & $\begin{array}{l}\text { Stochastically } \\
\text { created inland } \\
\text { patches }\end{array}$ & $\begin{array}{l}\text { Sustained } \\
\text { moderate } \\
\text { disturbance }\end{array}$ \\
\hline Sand movement & High & Moderate & Low \\
\hline Mean $(s d) \%$ sand cover & $85.8(9.4)$ & $68.1(14.4)$ & $70.1(8.2)$ \\
\hline Mean $(s d) \%$ litter cover & $4.5(6.3)$ & $14.6(11.2)$ & $13.1(7.7)$ \\
\hline Mean (sd) \% vegetation & $9.6(4.9)$ & $17.2(3.6)$ & $16.2(0.4)$ \\
\hline Mean species richness & $7.9(3.4)$ & $17.0(4.4)$ & $8.5(0.7)$ \\
\hline $\begin{array}{l}\text { Mean }(\text { sd) } C \text {. pitcheri } \\
\text { density per square meter }\end{array}$ & $2.6(2.1)$ & $2.1(1.2)$ & $0.9(0.4)$ \\
\hline
\end{tabular}

al. 1993). These populations exist primarily in early- to mid-successional habitat with more than $70 \%$ open sand and moderate amounts of sand movement (McEachern 1992, Bowles et al. 1993). Such open sand conditions are maintained between erosion cycles by intermediate wind and wave disturbance of upper beaches and foredunes, and may be available on windward exposure of secondary dune slopes. In blowouts, these conditions persist for several decades through the mid-successional vegetation stage (Table 8.1, Olsen 1958b). Populations in each of these habitats have an extinction probability linked to either periodic catastrophic erosion or to the effects of succession (McEachern 1992). C. pitcheri thus persists as a collection of populations repeatedly colonizing the transient habitats of dynamic coastal dune landscapes. Its adaptation to both landscape and local processes fits a metapopulation model.

\section{Pitcher's thistle metapopulation characteristics}

\section{Pitcher's thistle biology}

Cirsium pitcheri has low genetic diversity throughout its range, although a significant negative correlation in genetic similarity occurs with increasing dis- 
tance between widely separated populations (Loveless \& Hamrick 1988). The C. pitcheri genome is a subset derived from $C$. canescens Nutt., a central Great Plains sandhill thistle (Loveless \& Hamrick 1988). The C. pitcheri progenitor probably reached the Great Lakes sometime during the late-Wisconsin glaciation, likely through migration along sandy outwash habitats at glacial margins (Loveless \& Hamrick 1988) or by a single long-distance dispersal event (Johnson \& Iltis 1963). It became established during the period of rapid erosion, deposition and isostatic rebound that created the modern Great Lakes shorelines (Farrand \& Drexler 1985, Hansel \& Mickelson 1988). The Great Lakes dunes landscape apparently reinforced selection on a preadaptation to the shifting habitat mosaic of the continental interior dune ecosystem (Loveless 1984).

As with $C$. canescens, and $C$. rhothophilum Blake., a dune thistle of the southern Californian coast (Zedler et al. 1983), C. pitcheri appears adapted to the xeric conditions of open dunes. It has a deep taproot and a thick cuticle that gives a blue-green cast to its white-tomentose leaves. A monocarpic perennial, it requires five to eight years to reach maturity. Flowering is determinant, in inflorescences of up to 100 cream-colored flower heads. It has a mixed mating system that is predominantly outcrossing, although selfing is possible (Loveless 1984). It is pollinated by a variety of generalist bees, butterflies, and skippers over about a three-week midsummer flowering period. Seeds are large relative to other thistle species, and have a weakly attached pappus. They can disperse singly, blown by the wind, or as groups in inflorescences that fall from the parent plant. Primary seed dispersal is generally within four meters of parent plants (Keddy \& Keddy 1984, Loveless 1984, Ziemer 1989), and field germination is highest among buried seeds (Loveless 1984).

C. pitcheri does not reproduce vegetatively and so depends upon seed production for population growth. New habitats are most likely colonized through wind dispersal of single seeds or, rarely, entire seed heads. The mixed mating system thus appears adaptive for population establishment from single or related founders. If rates of colonization exceed rates of local extinction, then C. pitcheri metapopulations are likely to persist. Indeed, thistle patch densities are highest in large, unfragmented dune systems (Pavlovic et al. 1993) where mechanisms of dispersal and establishment appear sufficient for colonization.

\section{Life history traits and demography}

Many Cirsium pitcheri life history traits are temporally and spatially variable (Table 8.2), correlating with community successional status, rates and amounts of sand movement, grazing and insect predation pressure, recreational impact, and widespread landscape factors such as drought and various land manage- 
Table 8.2. Cirsium pitcheri life-history and demographic characteristics

\begin{tabular}{ll}
\hline \hline Characteristic & Study Results \\
\hline Flowering date & Late May to mid-September \\
Years to flowering & 3 to $11+$ \\
Flowering size & $10-63 \mathrm{~cm}$ tall, $1-12$ branches, \\
& $5-40 \mathrm{~cm}$ longest leaf \\
No. heads per adult & $4-31$ \\
No. seeds per plant & $289-572$ \\
Average seed weight & $0.009-0.013 \mathrm{~g}$ \\
Seed set date & June to September \\
Seed dispersal date & July to October \\
Seed dispersal distance & $0-5.5$ m, average $<2 \mathrm{~m}$ \\
Head dispersal distance & $0-4$ m, average $<1 \mathrm{~m}$ \\
Germination dates & June (peak) to August \\
\% Seeds damaged by larvae & $0-42$ \\
\% Germination - buried & $<2-73.3$ \\
$\%$ Germination - not buried & $0-3.3$ \\
\% Greenhouse germination & 10.2 \\
\hline \hline
\end{tabular}

Source: From Keddy \& Keddy 1984, Loveless 1984, Ziemer 1989, McEachern 1992

ment practices (Keddy \& Keddy 1984, Loveless 1984, Dobberpuhl \& Gibson 1987, Ziemer 1989). This variability produces a wide range of population structures across a dune system (McEachern 1992). Therefore, it is important to understand both local environmental effects on population demography and landscape-scale effects on metapopulations.

C. pitcheri habitat colonization and population persistence are aided by high phenotypic plasticity in such life history traits as relative growth rate, size at flowering, and seed production. For example, foredune plants mature more slowly and have higher seedling and juvenile mortality, but also have higher fecundity than plants in secondary dunes (Loveless 1984). Such plasticity could enhance growth of populations, while reducing variability in growth rates among populations. This would contribute to metapopulation persistence in a system where independent environmental events drive population dynamics (Goodman 1987a).

External abiotic and biotic factors can greatly influence $C$. pitcheri population demography. For example, large established plants can survive up to 20 $\mathrm{cm}$ of annual sand deposition but less than $4 \mathrm{~cm}$ of erosion, while seedlings cannot be established from seeds buried more than $8 \mathrm{~cm}$ (McEachern 1992); these responses influence population structure differently among habitats. Density-dependent predispersal seed predation of $C$. pitcheri by the plume moth, Platyptilia carduidactyla, was shown to reduce reproductive output by as much as $42 \%$ in a Canadian population (Keddy \& Keddy 1984). Other biotic 


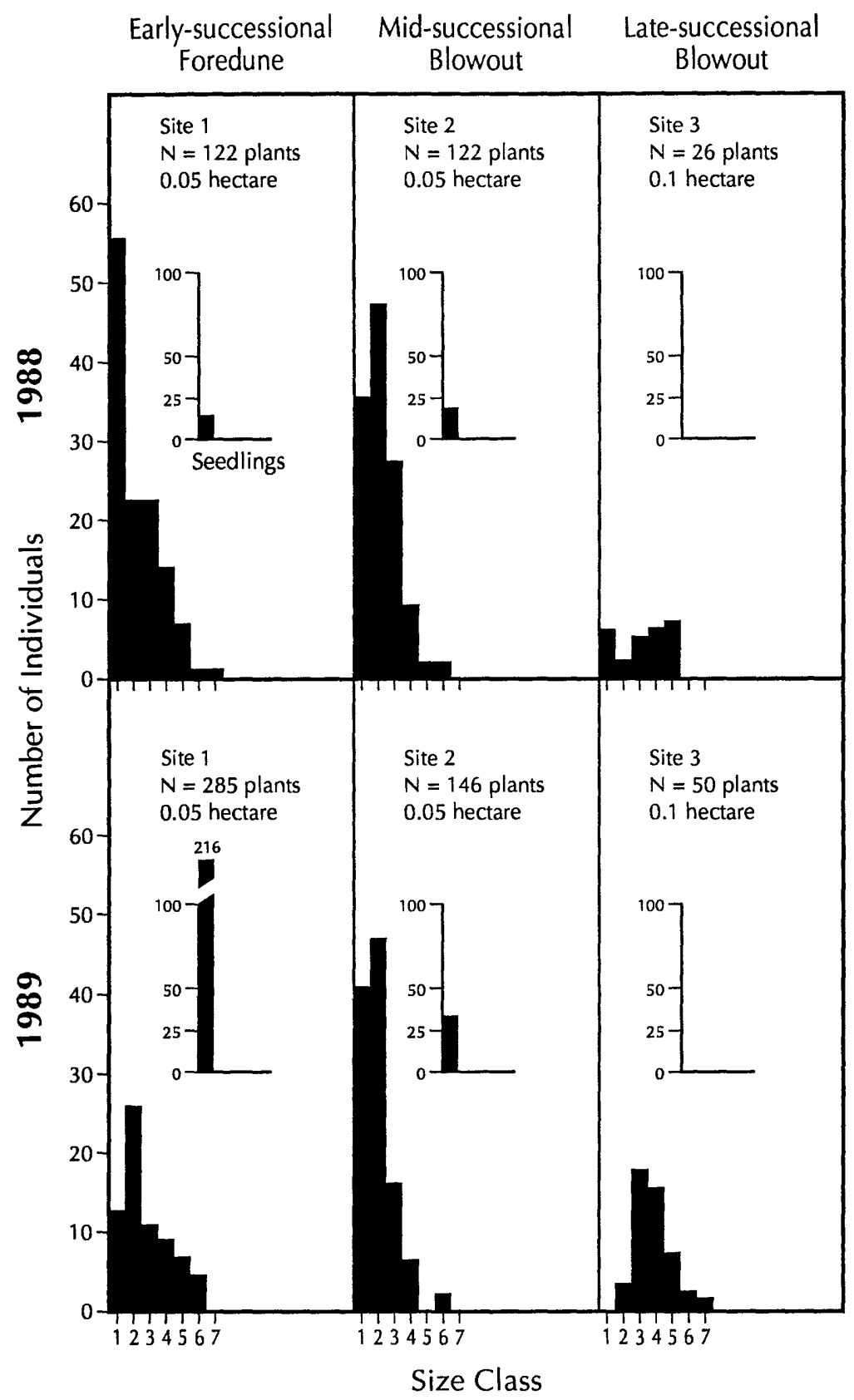

Fig. 8.4. Comparison of Cirsium pitcheri population structures over time in early- to late- successional Great Lakes dune communities, 1988 and 1989. See Fig. 8.2 for sources of population profiles. 
impacts on individual reproductive success include seed predation by goldfinches and ground squirrels (Loveless 1984) and foliage grazing by rabbits (McEachern 1992). In addition, recreational trampling can selectively eliminate smaller plants, thus skewing populations toward larger size-classes and increasing their potential for extinction (Dobberpuhl \& Gibson 1987).

In response to demographic variation, population size and structure can vary between years within and among populations (Fig. 8.4). Temporal variation in population structure buffers metapopulations against loss from widespread environmental catastrophes such as drought or outbreaks of seed-feeding insects. Similarly, population dispersion in space buffers metapopulations against catastrophes such as highly localized sand accretion. This illustrates why restoration and recovery management must consider both large-scale environmental heterogeneity and small-scale population demography.

\section{Pitcher's thistle recovery planning}

\section{Status and recovery goals}

Cirsium pitcheri historically inhabited intermittently stable beaches and open patches in grassland dunes of the Lake Michigan, Huron and Superior shorelines (Fig. 8.3, Cowles 1901, Gates 1912, Pepoon 1927, Peattie 1930, Guire \& Voss 1963). Because of increasing coastal development and changing shoreline dynamics, $C$. pitcheri has declined throughout most of its range, resulting in its federal listing (Harrison 1988). The most severe impacts have occurred along the southern tip of Lake Michigan, where shorelines have experienced a long history of intensive land use (Moore 1959, Fraser \& Hester 1974, Purdue University 1986). Few $C$. pitcheri populations remain in Indiana and Wisconsin, and it has been extirpated from Illinois.

Recovery and eventual delisting of endangered and threatened species is planned under provisions of the United States Endangered Species Act of 1973. Recovery for $C$. pitcheri is guided by 'Recovery 2000', a US Fish and Wildlife Service (1990) planning document, and the Pitcher's thistle federal recovery plan (Pavlovic et al. 1993). Recovery goals include identification and protection of suitable habitat throughout the species' range, amelioration of conditions that led to metapopulation decline, and recovery or restoration of metapopulations that can persist through time and space in a dynamic landscape (Pavlovic et al. 1993).

Because of its severe decline in the southern Lake Michigan region, federal recovery objectives include reintroduction of an historic $C$. pitcheri population to Illinois, and restoration of existing Indiana populations to a viable metapop- 
ulation (Pavlovic et al. 1993). Planning for reintroduction to Illinois requires identification of dune systems with appropriate landscape characteristics for C. pitcheri persistence. Restoration planning in Indiana requires identification of factors causing local population decline and colonization limitation. A metapopulation framework can then be used at both sites to link landscape and population processes with specific recovery prescriptions and management goals. The dune systems must be of sufficient size so that environmental processes do not affect all populations at the same time. The systems must have long-term management and protection that allow processes of dune building, erosion, and plant succession to operate. Techniques will vary between the Illinois and Indiana sites according to their landscape area, local habitat quality and availability, and habitat turnover. These provide opportunities to test our understanding of metapopulation function by applying different experimental designs for reintroduction and restoration in contrasting environments.

\section{Demographic and biological aspects of recovery}

Because Cirsium pitcheri is monocarpic, establishment of successive cohorts in restorations is required to avoid potential population extinction correlated with reproductive failure of a single cohort. Although the mixed mating system and low genetic diversity of this species may accommodate reintroductions based on seed samples from few parents, use of propagules collected from multiple parents might increase genetic diversity within reintroduced populations and thereby decrease inbreeding among closely related genotypes (Barrett \& Kohn 1991, Fenster \& Dudash, Chapter 2 of this volume). However, because of range-wide genetic differences between metapopulations, propagules used for recovery should be derived from sources near the reintroduction sites.

Controlling external biotic impacts on reproduction also appears critical in $C$. pitcheri recovery. Predispersal insect predation on flowers or seeds of $C$. canescens (Louda et al. 1990), C. rhothophilum (Zedler et al. 1983) and C. pitcheri (Keddy \& Keddy 1984, Loveless 1988, McEachern 1992) suggests that insects can limit population growth. Insect exclusion should have positive cumulative effects on seed production, seedling establishment, and population growth (Louda, Chapter 5 of this volume). Control of postdispersal seed predation and herbivory by birds and mammals (Loveless 1984) should also increase plant survival and population growth. Similarly, control of recreational impacts may be needed to enhance seedling establishment and cohort survival. Recovery experiments should produce 'win-win' situations in which knowledge is gained while reproduction is enhanced (Louda, Chapter 5 of this volume). 


\section{Physical aspects of recovery in Illinois and Indiana}

Potential metapopulation recovery sites in Illinois and Indiana are restricted to Illinois Beach State Park and the Indiana Dunes National Lakeshore and State Park. Both areas are large fragments of historically more extensive dune systems that supported Cirsium pitcheri. They are affected by recreation and by offshore structures that alter longshore currents and sand supply. Nevertheless, they are the largest undeveloped dune systems left in the extreme southern Lake Michigan basin, and they have long-term habitat protection. These systems differ in their landscape area, habitat availability, and habitat turnover because they are located in different positions on the Lake Michigan shoreline and are exposed to different sediment sources, longshore currents, prevailing winds, and storm tracks (Fig. 8.3).

Illinois Beach State Park is located $70 \mathrm{~km}$ north of Chicago, on a $1.5-\mathrm{km}$ wide ridge-and-swale sand deposit extending 22.6 kilometers along the Lake Michigan shoreline (Fig. 8.5). This sand deposit is transient in geologic time; it is undergoing progressive southward erosion and deposition by the longshore current and reaches a maximum age of 3600 years near the Illinois-Wisconsin state line (Larsen 1985). Its shoreline position also fluctuates in relation to cyclic lake level changes (Hester \& Fraser 1973), and erosion by the longshore current has accelerated (Fraser \& Hester 1974) owing to high lake levels and blockage of longshore current sand transport by shoreline structures. This erosion is ameliorated by periodic artificial sand replenishment.

The Indiana Dunes National Lakeshore and State Park is located at the extreme southern tip of Lake Michigan. The youngest dunes with open grassland habitat suitable for $C$. pitcheri formed during and after the Hypsithermal approximately 5000-3000 years ago. The shoreline has been adjusting to a new climatic equilibrium since then (Thompson 1989); the eastern Indiana Dunes shoreline is undergoing net erosion and landward displacement, while the western shoreline is accreting. This process has been altered locally in the Indiana Dunes by construction of revetments and offshore structures (Fig. 8.6). Deposition increased up-current from these structures from 1967 to 1984 , and down-current erosion occurred over the same time period. Thus, the Indiana Dunes shoreline is now in human-induced disequilibrium, and will remain so as long as sediment-control structures are maintained (Purdue University 1986). This has important implications for ecosystem management.

A serious impediment to $C$. pitcheri recovery at both sites is that the upper beach, once typical thistle habitat (Cowles 1899, Gates 1912) and potential linkage between populations, may no longer be suitable habitat because disturbances from recreational use and accelerated shoreline erosion exceed thresh- 


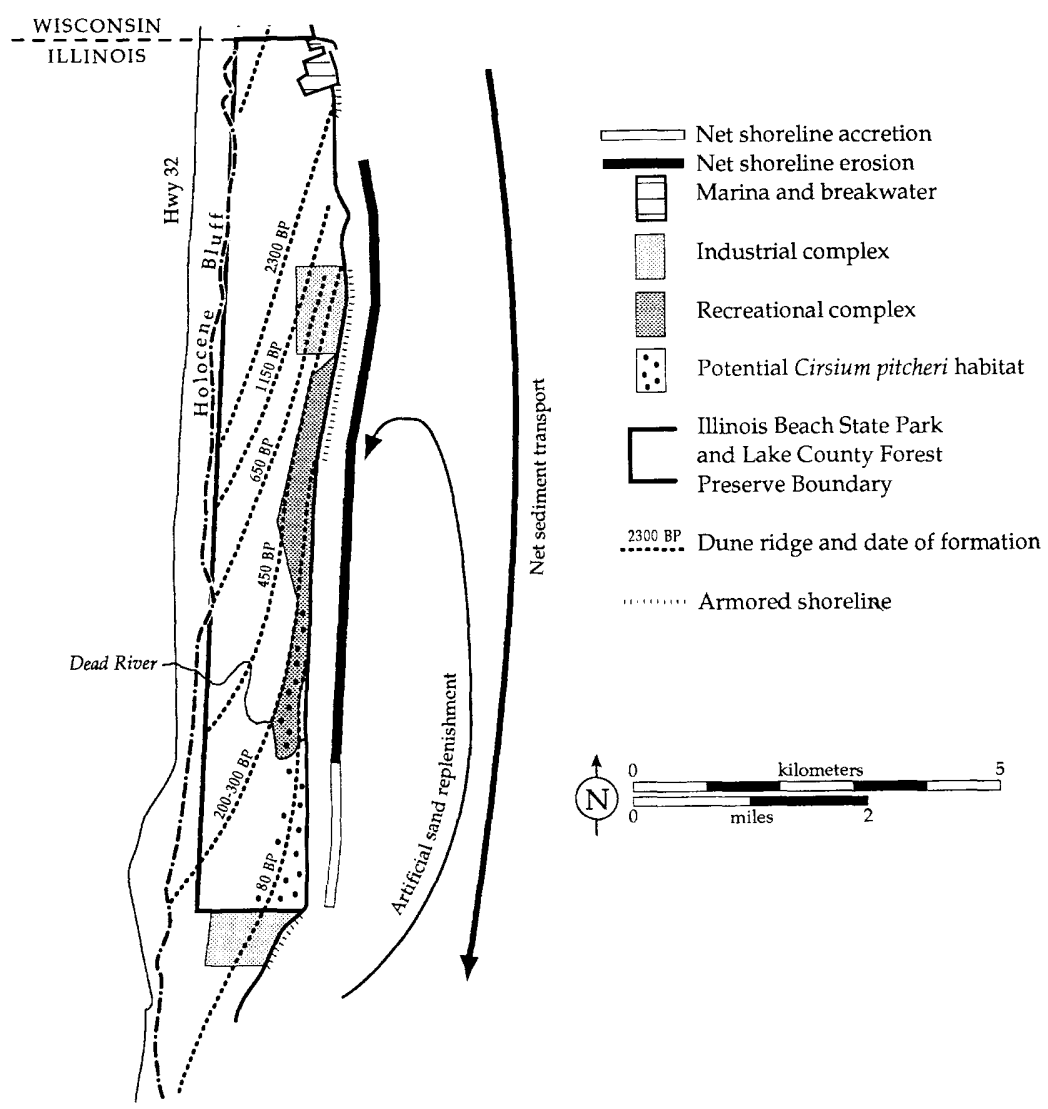

Fig. 8.5. Shoreline dynamics and potential Cirsium pitcheri habitat at Illinois Beach State Park, Lake County, Illinois.

olds for thistle persistence and completion of life cycles. Although beach replenishment might appear to benefit $C$. pitcheri recovery, it does not prevent erosion and thus may not protect thistles. Thus, restoration of natural shoreline dynamics may be required before beaches can resume their role as linkages in metapopulation dynamics.

\section{The recovery strategy in Illinois}

\section{Thistle decline and modern habitat conditions}

Cirsium pitcheri is now extirpated from Illinois. Former habitat descriptions are mostly vague notes (e.g. 'dunes,' 'sandy shoreline,' and 'dry sand beaches') in plant collection records made between 1862 and 1919 (Bowles et al. 


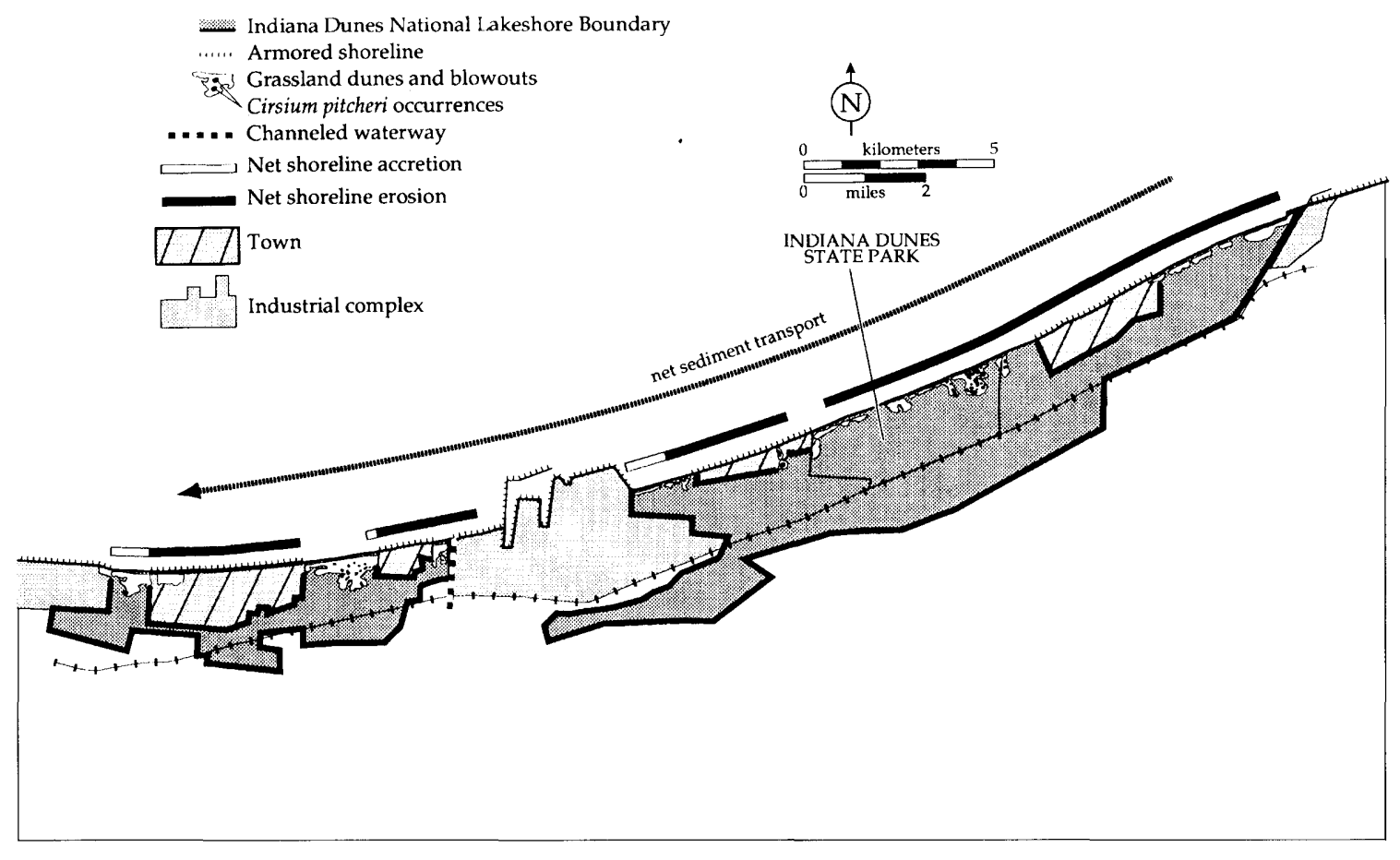

Fig. 8.6. Cirsium pitcheri population distribution, habitat fragmentation and shoreline dynamics at Indiana Dunes National Lakeshore and State Park. 


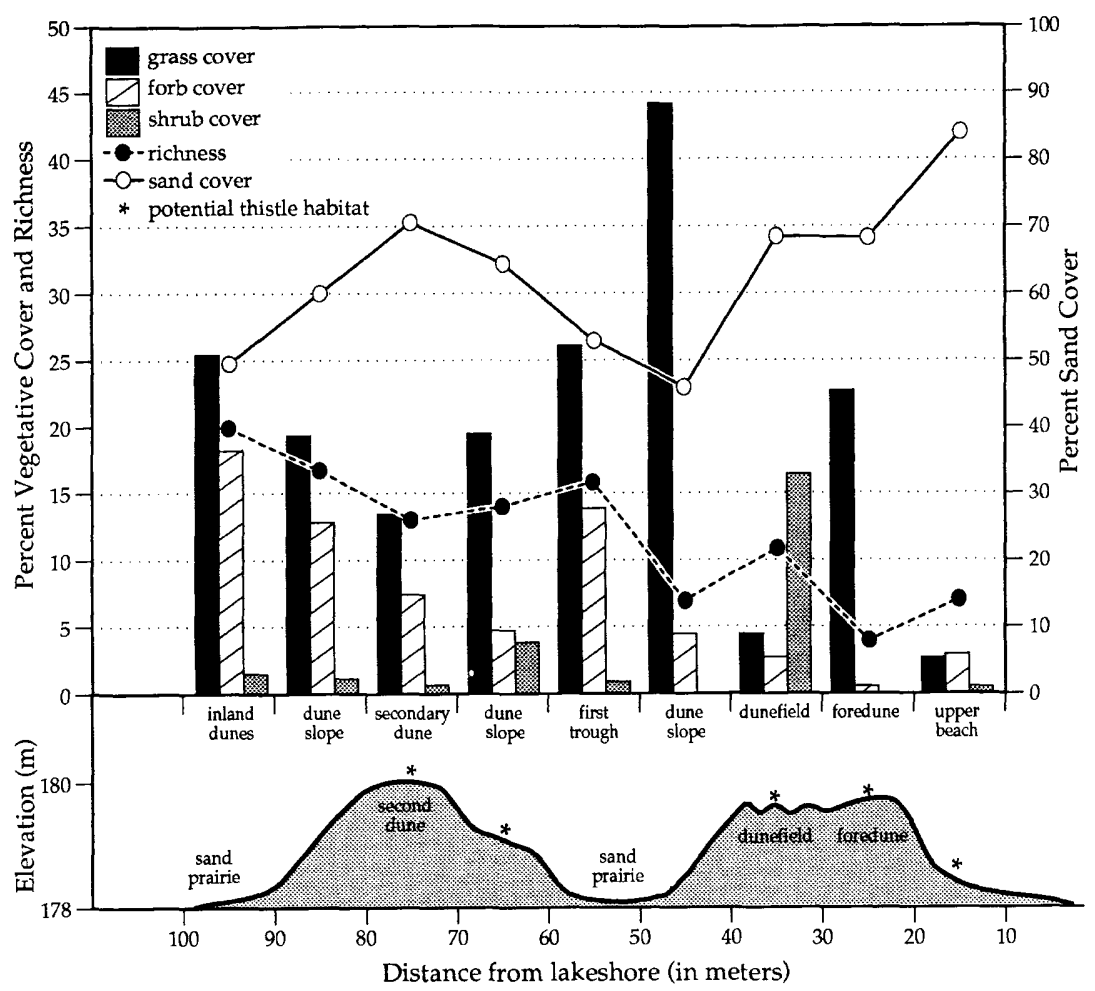

Fig. 8.7. Change in plant community structure and potential Cirsium pitcheri habitat across a dune and swale habitat gradient at Illinois Beach State Park, Lake County, Illinois.

1993). Only Gates (1912) provided a specific habitat description, from observations of plants in the upper beach association (sensu Cowles 1899) in an area now protected as part of Illinois Beach State Park. It is likely that by 1912 , increasing shoreline use was already impacting a narrowly-distributed population highly susceptible to over-collecting, beach use, and the environmental, demographic, and genetic causes of extinction in small populations. Apparently the plants disappeared rapidly. Only one subsequent Illinois Beach collection was made (in 1919), and Pepoon (1927) did not mention C. pitcheri in his lengthy discussion of the same area studied by Gates.

The landscape in the southern part of Illinois Beach is of sufficient size and condition to support experimental reintroduction of a thistle metapopulation. It contains natural disturbance-mediated successional community gradients that extend inland from Lake Michigan across the upper beach, foredune, and older dune ridges and swales (Fig. 8.7), and southward along the accreting shoreline. 
The beach ridges are compressed into a narrow dunefield north of the Dead River, but are more widely spaced as they accrete southward. Climatic lake level cycles and the southward shoreline migration provide shifting disturbance zones to which thistle metapopulations are adapted. Habitats south of the Dead River are in natural condition and free of recreational impact. The dunefield north of the Dead River was formerly conifer-forested (Gates 1912, Pepoon 1927), but is now open and used for recreation. This use may help maintain disturbance conditions suitable for Pitcher's thistle; however, trampling could limit the establishment and survival of seedlings (Dobberpuhl \& Gibson 1987).

\section{Thistle recovery in Illinois}

A primary step in restoring $C$. pitcheri to Illinois Beach is the identification of microhabitats along the dune system successional gradients that provide necessary conditions to support thistle populations. Potential habitats that are within colonizing distance of one another, yet only weakly environmentally correlated, are needed to maintain metapopulation dynamics. This juxtaposition would allow thistles to colonize from established populations along a shifting successional gradient while being buffered against local stochastic environmental impacts.

In the abșence of clear historic $C$. pitcheri habitat descriptions for Illinois Beach, ordination and cluster analysis of plant community characteristics were used to compare potential Illinois habitats with those currently supporting thistle populations in Indiana and Wisconsin (Bowles et al. 1993). These comparisons provided correlations at the landscape and microhabitat scale. At Illinois Beach, habitats with greater than $65 \%$ bare sand cover included the upper beach and foredune, the secondary dune top and dune slope, and the dunefield (Fig. 8.7). These sites clustered within groups that contained Indiana and Wisconsin habitats supporting C. pitcheri populations, indicating a strong similarity in community composition within clusters, and thus potential for the Illinois habitats to support $C$. pitcheri reintroduction.

The optimum habitats for population reintroduction appear to be the secondary dune top and dune slope, which are free from shoreline erosion, competition, and recreational impact. The dunefield is similar to thistle habitat in Wisconsin, and its high sand cover suggests that it may be suitable for population maintenance. However, its low grass cover apparently results from trampling, which could negatively impact thistle seedlings. The upper beach and foredune at Illinois Beach also appear to meet habitat criteria for thistle population maintenance, but erosion and periodic beach nourishment rates may be 
too great for thistle establishment and survival. Therefore, the secondary dune foreslope and ridge top were chosen for initial population reintroduction.

Cirsium pitcheri restoration began in the secondary dune habitat at Illinois Beach in 1991, with the experimental planting of 77 first-year juvenile plants grown from southeastern Wisconsin and northwestern Indiana seeds (Bowles et al. 1993). The planting strategy was based on known characteristics of thistle populations, and avoided factors associated with mortality (Loveless 1984, Louda, Potvin \& Collinge 1990, McEachern 1992, Louda, Chapter 5 of this volume). Seeds were collected from multiple parents to accommodate the mixed mating system of this species, and to maximize genetic diversity. Seedlings were germinated and propagated in a greenhouse, and then transplanted in order to avoid postdispersal seed predation and the high mortality associated with small seedlings. Initial field experiments found Indiana seedlings to significantly outperform Wisconsin seedlings in growth and survivorship, and no significant impacts from grazing (Bowles et al. 1993).

Since planting of greenhouse stock avoids environmental selection that might occur during seedling establishment, experimental seed dispersal will supplement the plantings. Insecticide treatment of flowering plants will be used to deter seed predators, while seed collection and planting will enhance seedling establishment, thus developing a 'win-win' experimental approach to restoration (sensu Louda, Chapter 5 of this volume). Subsequent plantings will expand the population size and extent, and allow development of cohort structures that mimic natural populations. This will enhance potential for population persistence as the microhabitats shift along the successional gradient in time and space.

Although the secondary dune population may persist and shift spatially with shoreline position as lake levels fluctuate in the future, establishment of an environmentally independent second population is critical for recovery success. The dunefield is potential habitat for such a second population. If beach and foredune habitat can serve as a migratory corridor connecting the dunefield and secondary dune habitats, metapopulation scale recovery may be achieved at Illinois Beach. However, successful metapopulation maintenance will require further experimentation and management. This would include evaluating the impact of recreation on seedlings in dunefield habitat and monitoring impacts of beach erosion and replenishment rates on thistle colonization of upper beach and foredune habitats. Supplemental planting and experimentation to maximize population size and cohort diversity may be a key to overcoming extinction thresholds and allowing colonization of new habitats. 


\section{The recovery strategy in Indiana}

\section{Thistle decline and modern habitat conditions}

Cirsium pitcheri is a former component of the Indiana upper beach and foredune flora (Cowles 1899, Pepoon 1927), and Olson (1951) found it along transects in nearshore secondary dune blowout locations in the 1940s. Populations now exist in only eight of the blowouts scattered throughout the western portion of the Indiana Dunes National Lakeshore and State Park, although apparently good thistle habitat exists in all blowouts (Fig. 8. 6). It is absent from the eastern one-third of the National Lakeshore, where natural erosion has been augmented by the effects of ditches, jetties, breakwaters and revetments. Its current absence from Indiana beaches and foredunes may result from natural disturbance exacerbated by human use.

Cyclic high lake levels almost completely erode beaches and foredunes in the Indiana Dunes area. The foredunes rebuild naturally within several years following lake recession in locations still supplied by sand through longshore sediment transport (Cowles, 1899, 1901; Peattie 1930; Olson 1958b; Purdue University 1986; Thompson 1989). If cyclic erosion has long been a component of the natural disturbance regime, then blowouts have served as habitat refugia for $C$. pitcheri during high lake levels. Beach and foredune recolonization could occur from blowout populations between erosional episodes, providing metapopulation linkage between blowouts. However, human use of the Chicago area beaches has been consistently intense since the late $1800 \mathrm{~s}$ (Moore 1959). Given the apparent susceptibility of $C$. pitcheri to trampling (Dobberpuhl \& Gibson 1987), it may be eliminated from beaches and foredunes by recreational use, and it is unlikely that it will reestablish there as long as beach use continues.

\section{Thistle recovery in Indiana}

The Indiana Dunes National Lakeshore and State Park can be viewed as a metapopulation landscape unit, with populations historically linked through intermittent beach corridors. Such a view allows specific hypotheses about metapopulation functioning to be generated within a management framework. C. pitcheri is declining at Indiana Dunes because of problems (Table 8.3) at both the population and metapopulation levels (McEachern \& Pavlovic 1991). Some of these can be addressed by restoration treatments now, while others are beyond current economic and legislative management capacity and must be left as long-term restoration goals. 
Table 8.3. Cirsium pitcheri metapopulation persistence problems at Indiana Dunes National Lakeshore and State Park

\begin{tabular}{lc}
\hline \hline Problems at the population scale & Restoration at the population scale \\
Low reproductive output in isolated & Introduce seedlings to increase \\
populations & population size and genetic diversity \\
Deterministic elimination of individuals & Reduce vegetation and litter cover to \\
during plant succession & artificially retard succession \\
Low reproductive vigor or loss of plants & Exclude herbivores, fertilize or water \\
due to vertebrate and insect herbivory & adults to increase reproductive vigor \\
Catastrophic population loss due to & Plan and implement visitor use control \\
recreational impact & near populations through education, \\
& law enforcement, and boardwalk and \\
& trail development \\
Problems at the metapopulation scale & Restoration at the metapopulation scale \\
Colonization not occurring between & Establish new populations in suitable \\
distantly isolated suitable habitats & habitats between separated established \\
& populations \\
Barriers to dispersal in nearshore zone & Designate natural areas for species \\
created by heavy recreational use of & preservation in which visitor use is \\
beach and foredune & restricted \\
Barriers to seed dispersal created by & Purchase land and restore dune systems \\
housing and commercial developments & to suitable habitat \\
Sand delivery reduced by shoreline & Remove structures to restore sand flow \\
structures, causing shifts in landscape & \\
dynamics & \\
Shoreline erosion created by shoreline & Remove structures, initiate sand \\
structures, eliminating habitats & nourishment for shoreline restoration \\
\hline \hline
\end{tabular}

At the local scale, extirpation of many small populations appears imminent. Most populations are small and structurally fragmented. Over the past four years at three demographic study sites (McEachern 1992), plants reproduced at small sizes, seed maturation was poor, insect and goldfinch seed predation appeared to be high, seedlings were not establishing, and rabbit grazing was reducing juvenile plant vigor. In addition, high mortality is occurring among smaller size classes in areas heavily used by the public. Consequently, most Indiana Dunes populations are dysfunctional because of low local recruitment and failure to colonize new habitats.

Local $C$. pitcheri population decline probably results from interactions of several of these factors. Decline in some National Lakeshore sites is accelerated by heavy foot traffic. Several thistle habitats in the State Park that were open sand blowouts heavily used by the public at the turn of the century have now reached late-successional conditions. Prior to their protection as natural areas in the 1920s, these sites appeared fragmented and degraded in historic 
photos, much like some in the National Lakeshore today. Thus their recovery potential for thistles was initially low, and the effects of plant succession now exacerbate the problem. As a result, most $C$. pitcheri found in these late-successional blowouts are scattered in open patches maintained on slopes exposed to northerly winter winds. In addition, insect predation, rabbit grazing, and drought-induced mortality are higher at Indiana Dunes than in comparable areas farther north (McEachern 1992). Hypotheses that these historic and current environmental effects contribute to population degradation can be tested in the process of restoration at the Indiana Dunes.

Experimental restorations are being conducted in declining local populations with the objectives of increasing population sizes, changing population growth rates from negative to positive, and dampening between-year variances in population growth. Treatments include watering and fertilizing to increase individual adult reproductive vigor, insecticide treatment of inflorescences to deter flower and seed predators, seed and seedling planting in areas protected from herbivores, and fencing of individual plants to exclude grazers. Plantings will be made in open microhabitats within late-successional blowouts, and in areas free from heavy foot traffic in recreational areas. In addition to these population manipulations, the National Lakeshore's management plan for the West Beach recreational area is being revised for the development of a trail system that guides visitors away from $C$. pitcheri locations. This should reduce habitat fragmentation from diffuse visitor use, and increase the chances for dune community recovery and $C$. pitcheri restoration success.

Unlike problems that affect individual plants at local scales, landscape-scale problems are related to population interactions. Two categories of landscape use interfere with potential pollen flow and habitat colonization by seed: 1) use that prevents interactions between populations and available habitats, and 2) use that alters landscape dynamics so that habitat does not exist. Blowouts within the Indiana Dunes that have no C. pitcheri (Fig. 8.6) have been isolated from colonization sources by commercial and residential developments for decades, exacerbated by the lack of incipient linkage through foredune and upper beach populations. Reestablishment of linkages appears unlikely in the face of current land use zoning and recreational beach use. Therefore, artificial reintroduction of genetically diverse populations to such isolated sites is essential to the maintenance of metapopulation structure. In addition, landscape fragmentation should decrease with continued planned acquisition of National Lakeshore land and dune community restoration, improving within-metapopulation linkage. Given the natural dynamics of shoreline erosion demonstrated by Thompson (1987), community restoration efforts may have a better chance 
of success in nearshore blowout sites to the west than in eastern portions of the National Lakeshore.

Landscape alteration that eliminates habitats requires longer-term planning for restoration of sand flow and shoreline dynamics along the southern tip of Lake Michigan. This restoration will require such costly actions as removal of jetties and other hard shoreline structures, or mechanical passage of sand around the structures. These problems transcend the National Lakeshore and State Park boundaries, and must involve legislative and market-driven incentives if they are to succeed. In the final analysis, $C$. pitcheri recovery at Indiana Dunes may be constrained by total landscape area and local habitat colonization opportunity. Therefore, realistic short-term goals for the area are the restoration of population vigor and landscape linkage to the extent possible under current legislative and economic conditions. Long-term goals are the restoration of shoreline dynamics to reestablish the landscape context within which the metapopulation functions.

\section{Conclusions}

Recovery strategies for Cirsium pitcheri must be viewed within the context of the highly dynamic environment to which this species is adapted. Within a dune system, discrete $C$. pitcheri populations may be viewed as components of a metapopulation in which they interact spatially and temporally through pollen flow and seed dispersal. Such metapopulations are dispersed across a range of habitats that differ by their topographic position and community successional status. Dune systems and habitat conditions change through time in response to storms and large-scale cyclic climate fluctuations, but local habitats may change independently, depending upon their positions relative to shoreline dynamics. As a result, component populations can vary in size, structure, and growth rates, and demographic patterns can be uncorrelated between populations.

Recovery and restoration of Cirsium pitcheri should be approached at both the local and landscape levels. Experimental testing of seedling and transplant survival is critical in reintroducing populations, such as in Illinois, and the establishment of successive cohorts appears essential in developing population structure. Experimental establishment across different habitats is also critical as an initial step in re-establishing metapopulation dynamics. Transplanting propagated plants can speed the establishment of population cohorts, but seed dispersal is needed to allow selection to operate at the dispersal stage, and to add all life-history stages to the experimental design. At the Indiana Dunes, intervention in declining populations will allow testing of the hypotheses that 
insect predation, grazing, trampling, sand movement and plant succession alter population structure. Monitoring will follow the effects of environmental amelioration on population demography, and will contribute to an understanding of the role of demographic variability among populations in metapopulation persistence.

The scale of spatial habitat dispersion differs between Indiana Dunes and Illinois Beach, and may allow different approaches to metapopulation recovery. However, linkage of populations at both sites requires management for natural shoreline processes. Long-term monitoring of $C$. pitcheri distribution is needed to determine how changing landscape patterns affect population persistence and contribute to metapopulation dynamics. The results of these observations and experiments should then be applicable to $C$. pitcheri populations in other areas.

Even without experimental results that clarify mechanisms of metapopulation function, it is clear that the fate of Cirsium pitcheri is closely tied to the fate of its landscape. Its decline parallels human alteration of dune systems and shoreline processes. In this case, preservation of the dune ecosystem is consistent with management for an individual species. Recovery management for $C$. pitcheri, therefore, must emphasize metapopulation and landscape protection, with the long-term maintenance of naturally functioning Great Lakes dune systems as an ultimate goal.

\section{Acknowledgments}

We thank the members of the federal Cirsium pitcheri recovery team (Pavlovic et al. 1993) for their insights into Pitcher's thistle ecology, distribution and recovery potential.

\section{Literature cited}

Barrett, C. H. \& Kohn, J. R. (1991). Genetic and evolutionary consequences of small population size in plants, implications for conservation. In Genetics and Conservation of Rare Plants, ed. D. A. Falk \& K. E. Holsinger, pp. 3-30. New York: Oxford University Press.

Bird, E. C. F. \& Schwartz, M. L. (1985). The World's Coastline. New York: Van Nostrand Reinhold.

Bowles, M. L., Flakne, R., McEachern, A. K. \& Pavlovic, N. B. (1993). Recovery planning and reintroduction of the Federally threatened Pitcher's thistle (Cirsium pitcheri) in Illinois. Natural Areas Journal 13, 164-70.

Cowles, H. C. (1899). Ecological relations of the vegetation on sand dunes of Lake Michigan. Botanical Gazette, 27, 95-117, 167-202, 281-308, 361-88.

Cowles, H. C. (1901) The physiographic ecology of Chicago and vicinity. Botanical Gazette, 31, 73-108, 145-82. 
den Boer, P. J. (1981) On the survival of populations in a heterogeneous and variable environment. Oecologia 50, 39-53.

Dobberpuhl, J. M. \& Gibson, T. J. (1987) Status surveys and habitat assessment of plant species. I. Cirsium pitcheri (Torr.) Madison, T. \& G.: Wisconsin Department of Natural Resources.

Dorr, J. A. \& Eschman, D. F. (1971) Geology of Michigan. Ann Arbor: University of Michigan Press.

Farrand, W. R. \& Drexler, C. W. (1985) Late Wisconsin and Holocene History of the Lake Superior basin. In Quaternary Evolution of the Great Lakes, Special Paper 30, ed. Carrow, P.F. \& Calkins, P.E., pp. 17-32. Geological Association of Canada.

Fraser, G. S. \& Hester, N. C. (1974) Sediment distribution in a beach ridge complex and its application to artificial beach replenishment. Environmental Geology Notes EGN 67. Urbana: Illinois State Geological Survey.

Gates, F. G. (1912) The vegetation of the beach area in northeast Illinois and southeastern Wisconsin. Bulletin Volume IX, Article V. Urbana, Illinois: Illinois State Laboratory of Natural History.

Gilpin, M. E. (1987) Spatial structure and population vulnerability. In Viable Populations for Conservation, ed. Soulé, M. E., pp. 125-39. Cambridge University Press.

Gilpin, M. E. \& Hanski, I. eds. (1991) Metapopulation Dynamics: Empirical and Theoretical Investigations. New York: Academic Press.

Gilpin, M. E. \& Soulé, M. E. (1986) Minimum viable populations: processes of species extinction. In Conservation Biology: The Science of Scarcity and Diversity, ed. Soulé, M.E., pp. 19-34. Sunderland, Massachusetts: Sinauer Associates.

Goodman, D. (1987a) The demography of chance extinction. In Viable Populations for Conservation, ed. Soule, M.E., pp. 11-34. Cambridge University Press.

Goodman, D. (1987b) How do any species persist? Lessons for conservation biology. Conservation Biology, 1, 59-62.

Guire, K. E. \& Voss, E. G. (1963) Distributions of distinctive plants in the Great Lakes region. Michigan Botanist 2, 99-114.

Hands, E. B. (1970). A geomorphic map of Lake Michigan shoreline. In Proc. 13th Conference on Great Lakes Research, ed. Anderson, D. V. \& Seddon, J. S., pp. 250-65. International Association of Great Lakes Research. Detroit: Great Lakes Research Center, US Lake Survey.

Hansel, A. K. \& Mickelson, D. M. (1988) A reevaluation of the timing and causes of high lake phases in the Lake Michigan basin. Quaternary Research 29, 113-28.

Harrison, W. F. (1988) Endangered and Threatened Wildlife and Plants: determination of threatened status for Cirsium pitcheri. Federal Register, 53, No. 137, 27137-141.

Hester, G. S. \& Fraser, N. C. (1973) Sedimentology of a beach ridge complex and its significance in land-use planning. Environmental Geology Notes EGN 63. Urbana: Illinois State Geological Survey.

Johnson, M. F. \& Iltis, H. H. (1963) Preliminary reports on the flora of Wisconsin. No. 48. Compositae I-Composite family. Transactions of the Wisconsin Academy of Arts and Sciences, 52, 255-342.

Keddy, C. J. \& Keddy, P. A. (1984) Reproductive biology and habitat of Cirsium pitcheri. Michigan Botanist, 23, 57-67.

Lande, R. (1988a) Genetics and demography in biological conservation. Science, 241, $1455-60$.

Lande, R. (1988b) Demographic models of the Northern Spotted Owl (Strix occidentalis caurina). Oecologia, 75, 601-7. 
Larsen, C. E. (1985) A stratigraphic study of beach features on the southwestern shore of Lake Michigan: new evidence of Holocene lake-level fuctuations. Environmental Geology Notes EGN 112, Urbana: Illinois State Geological Survey.

Levins, R. (1970) Some mathematical questions in biology. In Lectures on Mathematics in the Life Sciences, Vol. 11, ed. Gerstenhaber, M., pp. 75-107. Providence, Rhode Island: American Mathematical Society

Louda, S. M., Potvin, M. A. \& Collinge, S. K. (1990) Predispersal seed predation, postdispersal seed predation and competition in the recruitment of seedlings of a native thistle in sandhills prairie. American Midland Naturalist, 124, 105-13.

Loveless, M. D. (1984) Population biology and genetic organization in Cirsium pitcheri, an endemic thistle. Ph.D. dissertation. Lawrence: University of Kansas.

Loveless, M. D. \& Hamrick, J. M. (1988) Genetic organization and evolutionary history in two North American species of Cirsium. Evolution, 42, 254-65.

Marsh, W. M. \& Marsh, B. D. (1987) Wind erosion and sand dune formation on high Lake Superior bluffs. Geografiska Annaler, 69, 379-91.

McEachern, A. K. (1992) Disturbance dynamics of Pitcher's thistle (Cirsium pitcheri) in Great Lakes sand dune landscapes. Ph.D. dissertation, Madison: University of Wisconsin.

McEachern, A. K. \& Pavlovic, N. B. (1991) Metapopulation dynamics in species recovery planning: Pitcher's thistle as an example, poster abstract. 53rd Midwest Fish and Wildlife Conference Proceedings. DesMoines: Iowa Department of Natural Resources.

Menges, E. S. (1990) Population viability for an endangered plant. Conservation Biology, 4, 52-62.

Moore, P. A. (1959) The Calumet Region: Indiana's Last Frontier. Indiana Historic Collections, vol. 39. Indianapolis: Indiana Historic Bureau.

Murphy, D. D., Freas, K. E. \& Weiss, S. B. (1990) An environment-metapopulation approach to population viability analysis for a threatened invertebrate. Conservation Biology, 4, 41-51.

Olson, J. (1951) Vegetation-substrate relations in Lake Michigan sand dune development, Ph.D. dissertation, Chicago: University of Chicago.

Olson, J. (1958a) Lake Michigan dune development. 3. Lake-level, beach and dune oscillations. Journal of Geology, 66:473-83.

Olson, J. (1958b) Rates of succession and soil changes on southern Lake Michigan sand dunes. Botanical Gazette, 119, 125-70.

Pavlovic, N. B, Bowles, M. L., Crispin, S., Gibson, T., Herman, K., Kavetsky, R., McEachern, A. K. \& Penskar, M. (1993) Pitcher's Thistle (Cirsium pitcheri) Recovery Plan. Minneapolis: U.S. Department of the Interior, Fish and Wildlife Service.

Peattie, D. C. (1930) Flora of the Indiana Dunes. Chicago: Field Museum of Natural History.

Pepoon, H. S. (1927) An Annotated Flora of the Chicago Area. Chicago: Chicago Academy of Sciences.

Purdue University. (1986) Indiana Dunes National Lakeshore shoreline situation report: executive summary. West Lafayette: School of Civil Engineering, Great Lakes Coastal Research Laboratory.

Saulesleja, A. (1986) Great Lakes Climatological Atlas. Ottawa: Environment Canada.

Shaffer, M. L. (1981) Minimum population sizes, species and conservation. BioScience, 31, 131-4.

Thompson, T. A. (1987) Sedimentology, internal architecture, and depositional 
history of the Indiana Dunes National Lakeshore and State Park. Ph.D. dissertation, Bloomington: Indiana University.

Thompson, T. A. (1989) Anatomy of a transgression along the southern shore on Lake Michigan. Journal of Coastal Research 5, 711-24.

U.S. Fish and Wildlife Service. (1990) Recovery 2000. Twin Cities, Minnesota: U.S. Fish and Wildlife Service Endangered Species Division.

Zedler, P. H., Fuehlstorff, K. G., Scheidlinger, C. \& Gautier, C. R. (1983) The population ecology of a dune thistle Cirsium rhothophilium (Asteraceae). American Journal of Botany, 70, 1516-27.

Ziemer, L. S. (1989) A study of factors limiting the number and distribution of Cirsium pitcheri. Lansing: Michigan Department of Natural Resources. 